\title{
POPULATION, BASKING AND HATCHING SUCCESS OF GAVIALIS GANGETICUS IN NARAYANI RIVER, CHITWAN NATIONAL PARK, NEPAL
}

\author{
S.L. Rajbhandari ${ }^{1}$ and P. Acharya ${ }^{2}$
}

\section{ABSTRACT}

This study was carried out to investigate the habitats and abundance of the Gharials in Narayani river of Chitwan National Park from 2012 to 2013. A total of 38 Gharials including 3 hatchlings, 8 juveniles, 12 sub-adults and 15 adults were recorded during the study period. Only one breeding male was observed reflecting the critical condition for the breeding in the wild within Chitwan National Park. The abundance of the gharial was restricted in 2 areas, namely Khoria muhan and Velaunji due to suitability of the habitat conditions and minimum human disturbances. The Basking activities in relation to depth showed that $>80 \%$ of the Gharials selected sandy banks. Among the 2 populations, the gharials in Khoria muhan preferred shallow to moderate depth of water because of presence of braided channels in the area. In contrast, the Gharials in Velaunji select deep water course of the main channel. The park management must adopt conservation measures such as ban of fishing and regular monitoring of habitats and population to maintain long term conservation of gharials in Narayani river.

Key words: Gharial crocodile, sandy banks, river depth, anthropogenic disturbances

\section{INTRODUCTION}

The Crocodile (Family Crocodylidae) is a large aquatic tetrapod that lives throughout the tropics in Africa, Asia, the Americas and Australia. lizards, snakes and crocodiles are all scaled diapsids but crocodiles are archosaurs which means they are genetically closer to birds and the extinct dinosaurs. Crocodylidae is classified as a biological family (Bustard and Singh 1978, Whitaker and Basu 1983). Adult males grow a bulbous nasal appendage, which resembles an earthen pot called a "Ghada", from which the species derives its name "Gharial"

Twenty-one species and seven sub-species of crocodiles are found globally where Nepal harbors only two species which are Gharial (Gavialis gangeticus), and Marsh crocodile (Crocodylus palustris). The gharial population has declined continuously over the years. Therefore, this species is listed as critically endangered species in IUCN Red Data List and included in the protected list as endangered reptile by National Park and Wildlife Protection Act, 1973.

Historically, Gavialis gangeticus was found in the northern part of the Indian subcontinent, in the river systems of Indus (Pakistan), Ganges (India and Nepal), Mahanadi (India) and Brahmaputra (Bangladesh, India and Bhutan). The presence of the species in the Irrawaddy river system in Myanmar has also been reported (Smith 1931). The gharial is typically a resident of flowing rivers with deep pools that have high sand banks and good fish stocks (Whitaker and Basu 1983, GCA 2008). Exposed sand banks are used for nesting. Although the function of 
the "Ghada" is not well understood, it is apparently used as a visual sex indicator, as a sound resonator, or for bubbling or other associated sexual behaviors (Martin and Bellairs 1977).

Gharial was previously present in all the Gangetic plain in several countries of south-east Asia (Pakistan, Bhutan, Myanmar, India, Nepal and Bangladesh). In 1940's, Gharial population was estimated from 5,000 to 10,000 individuals. It declined to 150-200 individuals in 1960's principally due to habitat destruction and uncontrolled exploitation. It's now only present in India and Nepal, about 1500 individuals in the wild of which 81 are found in Nepal (Khadka et al. 2008, DNPWC 2010).

In Nepal, Gharials were once distributed throughout the country in all the major river systems and their tributaries. Estimation before 1980s showed that Nepal has the population of about 57 Gharials while its population globally was just 200 in the wild (Dhakal et al. 2012). Currently, they are only small isolated populations in the Karnali, Babai, Rapti and Narayani river systems all of which are in and around the protected areas (Maskey and Mishra 1981, Andrews and Mac Eachern 1994, Maskey 1999).

This paper deals with the study on habitats, population status, and hatching success which could be beneficial in developing effective conservation measures to maintain the long term conservation of Gharials.

\section{STUDY AREA}

The study was carried out in Narayani river of Chitwan National Park (27034' to $27^{\circ} 68^{\prime} \mathrm{N}$ and $83^{\circ} 87^{\prime}$ to $84^{\circ} 74^{\prime}$ E) including the buffer zones from northern boundary of park (Sikrauli) to Tribeni barrage at international border with India. Chitwan National Park (CNP) is renowned for the conservation of some of the world's most endangered species, including Rhinoceros, Tiger, Gaur, and Gharial in their natural habitat (CNP Management Plan 1975-1979). The Park occupies an area of $932 \mathrm{~km}^{2}$ in the Rapti Valley of the Siwalik physiographic region, while the buffer zone $\left(27^{\circ} 28^{\prime} \mathrm{N}\right.$ to $27^{\circ} 70^{\prime} \mathrm{N}$ and $83^{\circ} 83^{\prime} \mathrm{E}$ to $84^{\circ} 77^{\prime} \mathrm{E}$ ) extends $750 \mathrm{~km}^{2}$ areas (fig. 1).

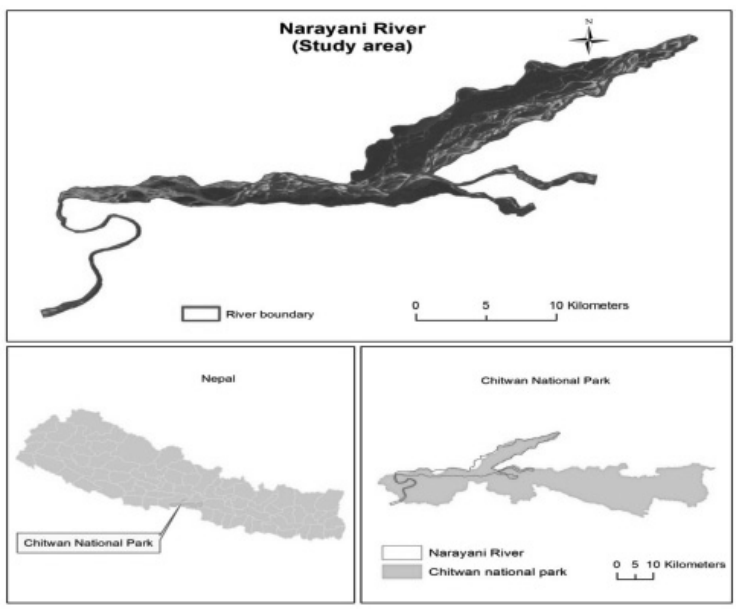

Figure 1. Study area in Narayani river, Chitwan National Park. 
Rajbhandari and Acharya : Population, Basking and Hatching.

The Narayani river is a snow fed river, formed by the large tributary of Kaligandaki and Trishuli rivers. The total length of this river is about $338 \mathrm{~km}$, and the average flow ranges 1000 to 1700 $\mathrm{cum} / \mathrm{s}$ but maximum flow ranges from 10 to $700,000 \mathrm{cum} / \mathrm{s}$ during the monsoon season from June to September (Panday 1987, Maskey 1989).

The Narayani river flows southwest for 30 kilometers from a gorge in the Mahabharat range to the Rapti confluence and then flows westward for a further 25 kilometers along the base of the Someswar hills before turning south through a very narrow gorge in the Siwaliks between the Daunney and Someswar hills until it reaches the Nepal-India border (Laurie 1978). The bed of the Narayani river is very broad consisting of a large number of channels and islands with a width of up to 4 kilometers. The floodplain varies with the altitude ranging from 250 meters to 150 meters.

The climate of Chitwan is subtropical with a summer monsoon from mid-June to late September and a relatively dry winter. The average annual rainfall is about $250 \mathrm{~cm}$, with the most occurring between June and September. The post-monsoon season between November and January is cool with the daily average temperature reaching $24^{\circ} \mathrm{C}$ during the day and droppings to about $7^{\circ} \mathrm{C}$ at night.

\section{MATERIALS AND METHODS}

The survey was conducted in two dugout canoes with four fishermen in January 2013 from Rapti-Narayani confluence area to Tribeni dam along Nepal-India border. The details of the gharial sighted with the help of Olympus binoculars were noted with their habitat features and GPS location.

\section{Population status}

The gharials were counted in January (winter) from 1000 and $1600 \mathrm{~h}$, a period coinciding with intensive basking frequency and aggregation of large Gharials for breeding (Hussain 2009). The gharials were classified into different size classes with an increment of $30 \mathrm{~cm}$. The individuals $<120 \mathrm{~cm}$ long were considered as hatchlings, $>120-180 \mathrm{~cm}$ as juveniles, $>180-270 \mathrm{~cm}$ as sub-adults and those $>270 \mathrm{~cm}$ as adults (Hussain, 2009). The sex of the sighted crocodile was also determined by presence or absence of nasal orifice. The details of the sighted Gharials such as substrate type, river width; mid-river depth and degree of human disturbances were estimated.

\section{Basking activity}

The temperature selection (either heat seeking or heat avoidance) within the available habitats is an important daily activity of all species of crocodiles. Therefore, basking in the sun during winter and remaining in water most of the time during summer regulates body temperature without much expenditure of energy and facilitates optimum metabolism.

The study of basking activity was conducted in the two areas, namely Khoriya Muhan and Velaunji. These areas were monitored for two weeks. The details of the sighted Gharials on both banks of the river as well as the mid-sandbars and islands were noted. These include their approximate size, basking site topography, substrate characteristics and the mid-river water depth and width. 


\section{Hatching success}

The percentage of survival of hatchlings from the time of hatching under artificial condition (dugout pits in Gohi project, Amaltari) till their transportion to the Gharial Breeding Center, Kasara for captive rearing is considered as hatching success. The period is about 15 days from the first emergence of hatchlings from the eggs and completion of all hatchings. The hatching success of the artificially incubated eggs in gharial project was studied. The details of the eggs such as the number of eggs hatched, eggs damaged, and hatchling mortality in each clutch collected from different nests were recorded.

\section{GIS analysis}

The field data such as GPS locations of Gharial survey and riverine habitat features have been visually interpreted from the Google Image 2010 after ground truthing. The data were generated by the screen digitization in Arc GIS 10.0 version to interpret the locations of the sighted Gharials and evaluate the habitat types utilized by the Gharials .

\section{RESULTS AND DISCUSSION}

\section{Population status}

Study was carried out in the Narayani river from Narayani-Rapti confluence to Tribeni at the international border with India. The survey recorded a total number of $38 \mathrm{Gharials}$ (fig. 2). Among the observed gharials, 3 were hatchlings, 2 juveniles, 12 sub-adults and 15 adults. Only one breeding male was recorded. The abundance of the Gharial population was mostly confined largely in three areas, namely, Khoriya, Seri and Velaunji (table 1 and 2). Among the Gharials observed in these areas, Khoriya had the largest congregation and Seri had only few numbers.

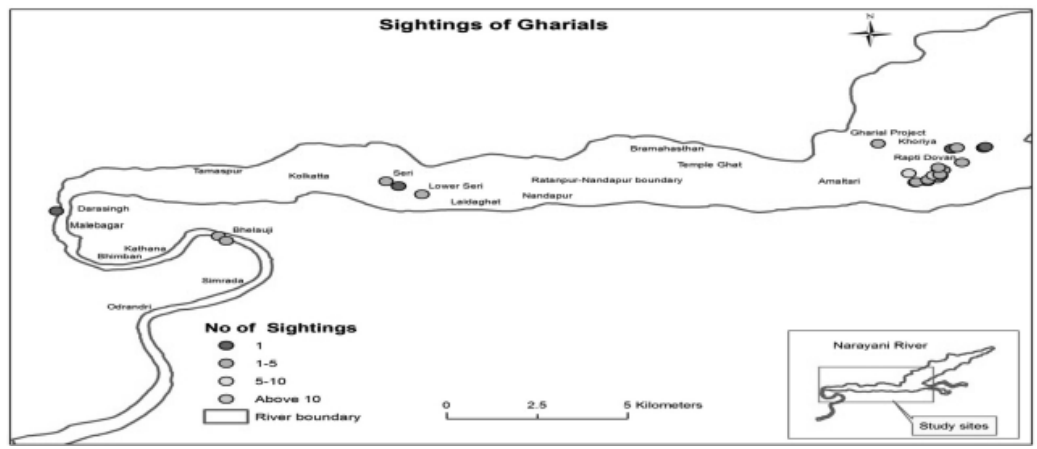

Figure 2. Sightings of Gharials.

Table 1. Gharial survey in the Narayani river, January 2013.

\begin{tabular}{|l|l|l|l|l|l|l|}
\hline River & Hatchlings & Juveniles & Sub-adults & Adults & Total & Remarks \\
\hline Narayani & 3 & 8 & 12 & 15 & 38 & One breeding male \\
\hline Total & 3 & 8 & 12 & 15 & 38 & \\
\hline
\end{tabular}

Table 2. Size classes of Gharial seen in the Narayani river, CNP during 2013. 


\begin{tabular}{|l|l|}
\hline Size class of Gharial & $\mathbf{2 0 1 3}$ \\
\hline$<120 \mathrm{~cm}$ & 3 \\
\hline$>120-180 \mathrm{~cm}$ & 8 \\
\hline$>180-270 \mathrm{~cm}$ & 12 \\
\hline$>270$ & 115 \\
\hline Total & 38 \\
\hline
\end{tabular}

The monitoring study by CNP (CNP 2012) in Narayani and Rapti rivers, recorded altogether 87 Gharials, of which 52 were recorded in the $100 \mathrm{~km}$ stretch of Narayani river. The census of Gharial according to the age classes had maximum of sub-adults representation with a total number of 28 individuals and hatchling represents a minimum number with only 4 individuals (table 3 and 4).

Table 3. Results of Gharial counts in the Rapti and Narayani rivers, November 2012.

\begin{tabular}{|l|l|l|l|l|l|l|l|}
\hline $\begin{array}{l}\text { River/Location } \\
\text { of sightings }\end{array}$ & $\mathbf{k m}$ & Hatchlings & Juveniles & $\begin{array}{l}\text { Sub- } \\
\text { adults }\end{array}$ & $\begin{array}{l}\text { Adults } \\
\text { (M.F) }\end{array}$ & Total & Remarks \\
\hline Rapti & 50.0 & 0 & 9 & 22 & $4 \mathrm{f}$ & 35 & No male \\
\hline Narayani & 100 & 4 & 6 & 28 & 14 & 52 & One male \\
\hline Grand Total & 150 & 4 & 15 & 50 & 18 & 87 & \\
\hline
\end{tabular}

Source: CNP (2012)

Table 4. Size classes of Gharial seen in the Narayani river, CNP during 2012.

\begin{tabular}{|l|l|}
\hline Size class of Gharial & $\mathbf{2 0 1 2}$ \\
\hline$<120 \mathrm{~cm}$ & 4 \\
\hline$>120-180 \mathrm{~cm}$ & 6 \\
\hline$>180-270 \mathrm{~cm}$ & 28 \\
\hline$>270$ & 14 \\
\hline Total & 52 \\
\hline
\end{tabular}

Source: CNP (2012) 
In the basking areas, the water channels were from $1.2 \mathrm{~m}-4.5 \mathrm{~m}$ deep. In Khoriya population, the Gharials used the sand bars and rocks for basking with the river channels having $1.2 \mathrm{~m}$ $-2.7 \mathrm{~m}$ deep whereas in Velaunji, the basking sites were only on sand with maximum water depth of $3.6 \mathrm{~m}$ (fig. 3 and 4 ).

This study showed that more than 80 percent of Gharials selected sandy areas for basking activities followed by rocks with about 15 percent. No Gharials were observed in clay (table 5).

Table 5. Preference of basking types by Gharials in the Narayani river, CNP during January 2013.

\begin{tabular}{|l|l|l|}
\hline Basking site type & Number of Gharial observed & Percentage of habitat use \\
\hline Sandy & 32 & 84.21 \\
\hline Rocky & 6 & 15.78 \\
\hline Clay & 0 & 0 \\
\hline Total & 38 & 100 \\
\hline
\end{tabular}

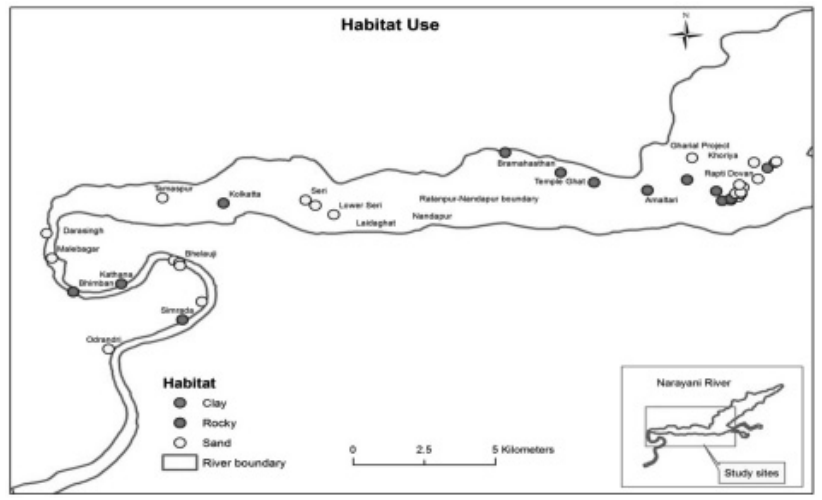

Figure 3. Habitat utilization by Gharials.

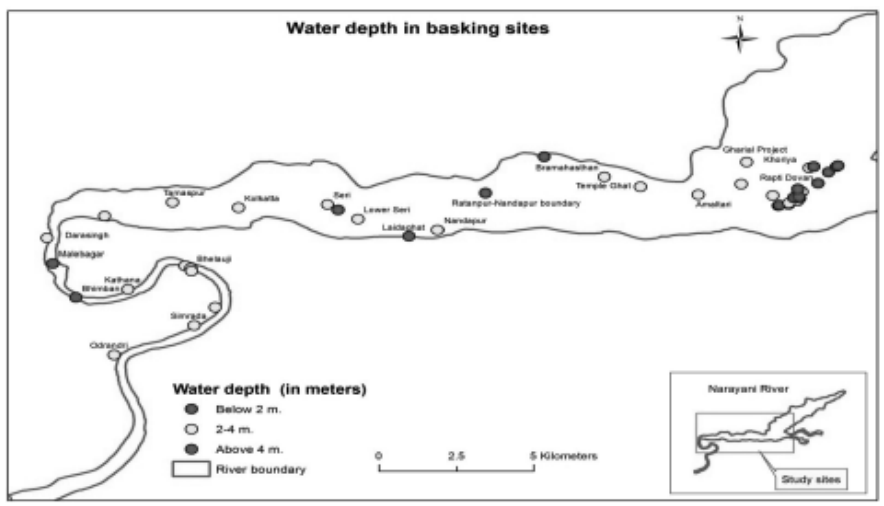

Figure 4. Water depth selection by Gharials. 


\section{Hatching success}

The reproductive effort during 2012 is summarized in table 6 . During this period, the mean clutch size of eggs was $31.6( \pm 8.61, \mathrm{~N}=5)$ with a maximum and minimum clutch size of 41 and 18 respectively. The mean incubation period was $72.5( \pm 2.82, N=4)$. The incubation period ranged from 70-78 days. The mean hatchling number was $6.2( \pm 5.01, N=5)$ with the total number of 31 hatchlings. The average percentage of eggs hatched is 19.6 with a maximum 50 percentage and a minimum 0 . Almost 50 percent of the eggs that were hatched were lost due to death by various reasons.

Table 6. Reproductive effort of Gharial in Narayani river, CNP in 2012.

\begin{tabular}{|l|l|l|l|l|l|l|l|l|l|l|}
\hline SN & $\begin{array}{l}\text { Egg } \\
\text { laying } \\
\text { date }\end{array}$ & $\begin{array}{l}\text { Loca- } \\
\text { tion }\end{array}$ & $\begin{array}{l}\text { Clutch } \\
\text { size }\end{array}$ & $\begin{array}{l}\text { Hatched } \\
\text { date }\end{array}$ & $\begin{array}{l}\text { Incu- } \\
\text { bation } \\
\text { period }\end{array}$ & $\begin{array}{l}\text { Hatch- } \\
\text { ling } \\
\text { no. }\end{array}$ & $\begin{array}{l}\text { \% of } \\
\text { eggs } \\
\text { hatched }\end{array}$ & $\begin{array}{l}\text { Death } \\
\text { during } \\
\text { hatch- } \\
\text { ing }\end{array}$ & $\begin{array}{l}\text { Post- } \\
\text { hatch- } \\
\text { ing } \\
\text { mortal- } \\
\text { ity }\end{array}$ & $\begin{array}{l}\text { In- } \\
\text { fer- } \\
\text { tile } \\
\text { eggs }\end{array}$ \\
\hline 1. & 5 April & $\begin{array}{l}\text { Khoriya } \\
\text { Muhan }\end{array}$ & 18 & 14 June & 71 & 9 & 50.0 & 0 & 0 & 9 \\
\hline 2. & $\begin{array}{l}31 \\
\text { March }\end{array}$ & $\begin{array}{l}\text { Hattisar, } \\
\text { Khoriya }\end{array}$ & 36 & 16 June & 78 & 8 & 22.2 & 0 & 7 & 21 \\
\hline 3. & $\begin{array}{l}31 \\
\text { March }\end{array}$ & $\begin{array}{l}\text { Bhelauji } \\
41\end{array}$ & 16 June & NA & 0 & 0.0 & 0 & 40 & 1 \\
\hline 4. & 4 April & Bhelauji & 33 & 15 June & 71 & 12 & 36.3 & 0 & 19 & 2 \\
\hline 5. & 5 April & Bhelauji & 30 & 15 June & 70 & 2 & 6.6 & 0 & 10 & 18 \\
\hline & $\begin{array}{l}\text { Sub- } \\
\text { Total }\end{array}$ & & 158 & & & 31 & 19.6 & 0 & 76 & 51 \\
\hline
\end{tabular}

\section{Human disturbances}

The study identified overfishing as the principal threat to the Gharials (fig. 5). In addition industrial pollution, construction of Tribeni dam, entangling of Gharials in fishing nets and increasing human disturbances in the river have severely threatened the Gharials and their habitat. 


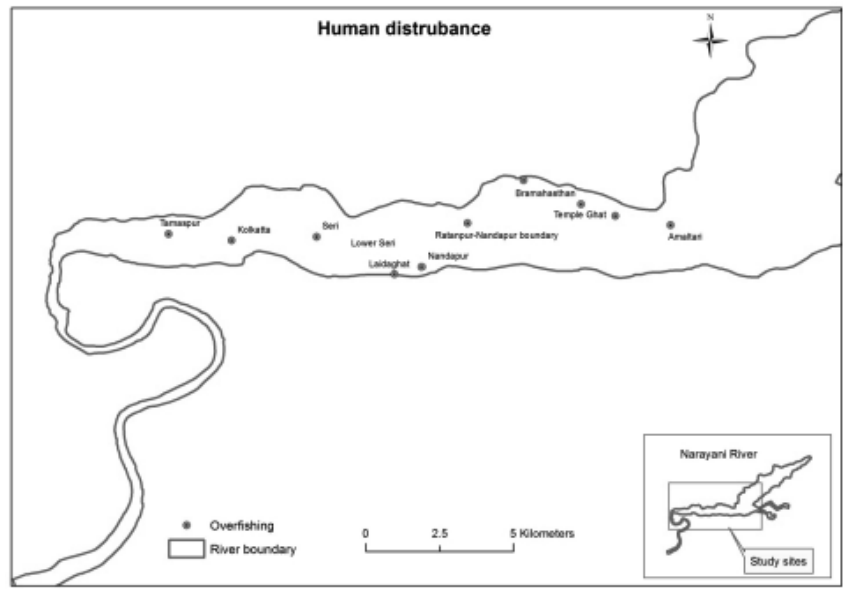

\section{Figure 5. Human disturbances in Narayani river.}

This study recorded altogether 38 Gharials including 3 hatchlings (7.8\%), 8 juveniles $(21.0 \%)$, 12 sub-adults (31.5\%) and 15 adults (39.4\%). This signified the representation of adults most followed by sub-adults, juveniles and hatchlings. The CNP 2012 Gharial survey recorded a total number of 52 Gharials (CNP 2012). This included 4 hatchlings (7.6\%), 6 juveniles (11.5\%), 28 sub-adults $(53.8 \%)$ and 14 adults $(26.9 \%)$ which reflected the dominance of sub-adults. Both studies identified a single breeding male in the Narayani river. The monitoring and protection to this breeding male is highly essential to promote breeding.

This study suggested congregations of Gharial population, particularly in two sections of the Narayani river (Rapti-Narayani confluence-Khoria Muhan and Velaunji). It can be concluded that less human disturbances in riverine areas due to regulation of fishing activities have resulted in the presence of gharials in large numbers. In other areas of the river, this study did not record the Gharials which is attributed due to the increasing human disturbances such as fishing, grazing, extraction of sand and boulder and presence of a large Tribeni dam. Such increasing human disturbances have also resulted in the disappearance of otters through the loss of otter habitats in Narayani river (Acharya et al. 2010, Acharya and Rajbhandari 2012). Other studies also indicated the threats to the Gharial population by human disturbances and dam construction (Maskey 1987, Collares et al. 2000). The gharials from different areas tend to migrate to the habitats with sand bars and sandy islands with deep water courses to secure suitable habitat and prey.

The habitat features in Narayani and Rapti confluence is characterized by the presence of the main channel along with braided channels, sand bars between the channels and moderate to deep water river course. In this part of the river, there is also strict monitoring and patrolling by the park and Khoria army post. Therefore, the Gharials tend to aggregate in this area from the different parts of the river during the winter season.

In the downstream areas such as Velaunji, the riverine habitat is characterized by the stagnant 
Rajbhandari and Acharya : Population, Basking and Hatching.

conditions due to Tribeni dam. The river here flows in between the foothills of Mahabharat range and Churia range. The presence of single deep water channel and occurrence of elevated sandy areas on the eastern banks with low human disturbances have caused Gharials to prefer these sites. Additionally, these sites are important sites for breeding of Gharials where eggs are collected annually for artificial hatching.

In 2012, 3 nests of gharial eggs were collected from the Velaunji area (personal communication, Juthe Ram and Sante Bote, 2013). Altogether 53 nests were collected from the Narayani river during the 6 nesting seasons of 1977-81 and 1987 (Maskey 1987). During the study, only 5 nests with a total of 158 eggs were collected from Velaunji, Khoria Muhan and Hattisar Khoria. The significant reduction in the number of nesting sites over years is due to high fishing pressures. The fishermen use large gill nets (Tiyari) for fishing which collect many small to large fish causing reduction in the prey base. Occasionally, the Gharials get entangled in these nets.

During 2011 and 2012, the total number of eggs collected was 228 from 6 nests and 182 from 5 nests respectively (CNP 2011, CNP 2012). There is a significant reduction (30.7\%) in the number of eggs in 2012. This is attributed due to high human disturbances in the river basin. Similarly, there is also the reduction in the percentage of eggs hatched $(3.18 \%)$ from the collected eggs in 2012. Such reduction could be due to lack of improper management measures such as maintenance of required temperature and humidity during artificial incubation period and lack of appropriate skill in caring and handling of the eggs. Dhakal et al. (2010) also pointed that the collection of eggs from the river and keeping them safely in the appropriate temperature requires high technique and intensive care.

The management capability of Gharial breeding center is strong enough in supporting the conservation management of captive Gharials and also in strengthening in situ conservation. The gharials are threatened in the rivers by various factors. Industrial pollution, the presence of large dam in Tribeni, over-fishing, poaching and collection of eggs for medicinal values, and high current and floods during the summer season have resulted in the scarcity of food (Acharya et al. 2010, Acharya and Rajbhandari 2012 and Rajbhandari and Acharya 2013).

The gharials in Narayani river are under immense pressure (Acharya et al. 2010) from anthropogenic disturbances and barrage construction. The park should adopt appropriate conservation measures such as ban on fishing, promotion of prioritized researches and strengthening of the policies to address the conservation of Gharials so that their long term existence is ensured.

\section{ACKNOWLEDGEMENTS}

We appreciate the funding support from The Rufford Foundation, U.K. to carry out this research and the Department of National Parks and Wildlife Conservation for allowing permission and logistic support to accomplish this research in CNP. We express thanks to Mr. Bed Bahadur Khadka, Assistant Conservation Officer of CNP for his support during the field survey.

\section{REFERENCES}

Acharya, P.M., P. Lamsal, S. L. Rajbhandari, P. Shrestha, D. Neupane, M. Pathak, M. Niraula, H. M. Lama and B. Lama, 2010. Status and distribution of otters in Narayani river, Chitwan 
National Park. A fist phase research report, Rufford Foundation, U.K., 52 p.

Acharya, P.M. and S. L. Rajbhandari, 2012. Investigation of population status and habitats of Lutrogale perspicillata in Narayani river, Chitwan National park. A second phase research report, Rufford Foundation, U.K., 50 p.

Andrews, H. V. and P. McEachern, 1994. Crocodile conservation in Nepal. IUCN Nepal and USAID NGO Environmental management program, Kathmandu, Nepal, 28 p.

Bustard, H.R. and L.A.K. Singh, 1978. Studies on the Indian gharial Gavialis gangeticus (Gmelin) (Reptilia, Crocodilia). Change in terrestrial locomotory pattern with age. J. Bombay Nat. Hist. Soc., 74:534-536.

CNP, 2011. Annual Report (Sharwan 2067-Asadh 2068).

CNP, 2012. Annual Report (Sharwan 2068-Asadh 2069).

Collares-Pereira, M.J., I. Cowx, F. Ribeiro, J. Rodrigues and L. Rogado, 2000. Threats imposed by water resource development schemes on the conservation of endangered fish species in the Guadiana River basin in Portugal. Fisheries Manage. Ecol., 7:167-178.

Dhakal, M., J. B. Karki, K. Gaire and B.B. Khadka, 2012. Species conservation and breeding centers in Nepal. In Acharya, K.P. and M. Dhakal (eds) Biodiversity Conservation in Nepal: $A$ Success Story. DNPWC. pp 49-59.

DNPWC, 2010. Annual Report (Sharwan 2066-Asadh 2067).

Gharial Conservation Alliance, 2008. International Gharial Recovery Action Plan. Available on http://www. gharialconservation.org/PDF/GRAP.pdf.

Hussain, S.A., 2009. Basking site and water depth selection by Gharial Gavialis gangeticus Gmelin 1789 (Crocodylia, Reptilia) in National Chambal Sanctuary, India and its implication for river conservation. Aquatic Conservation-Marine and Freshwater Ecosystems. 19:127-133.

Khadka, M., H. Kafley, and B.P. Thapaliya, 2008. Population status and distribution of Gharial (Gavialis gangeticus) in Nepal. A monitoring report, WWF/Nepal and DNPWC, pp 41.

Laurie, A., 1978. The ecology and behavior of the greater one-horned rhinoceros. Ph.D. Dissertation, Univ. Cambridge, pp 450.

Martin, B.G.H. and A.D.A. Bellairs, 1977. The narial excresence and pterygoid bulla of the gharial, Gavialis gangeticus (Crocodilia). J. Zool. Lond., 182:541-558.

Maskey, T. M. and H. R. Mishra, 1981. Conservation of Gharial, Gavialis gangeticus. Nepal. In Majupuria, T. C. (ed) Wild is Beautiful,185-196.

Maskey, T.M., 1989. Movement and survival of captive-reared gharial, Gavialis gangeticus in the Narayani river, Nepal. Ph.D. Dissertation, the graduate school of the University of Florida, USA. Maskey TM., 1999. Status and conservation of Gharial in Nepal. ENVIS Bulletin on Wildlife and Protected Areas. Wildlife Institute of India: Dehra Dun, 2:95-99.

Panday, R. K., 1987. Effect of Altitude on the Geography of Nepal. Cent. Altitude Geography. Kathmandu. 
Rajbhandari, S.L. and P. Acharya, 2013. Study of habitat and population of endangered Gavialis gangeticus in Narayani river of Chitwan National Park, Nepal. A fist phase research report, Rufford Foundation, U.K., 25 p.

Smith, M.A., 1931. Loricata, Testudines. The Fauna of British India including Ceylon and Burma. Reptilia and Amphibia, Vol. I. Taylor and Francis: London.

Whitaker, R. and D. Basu,1983. The Gharial (Gavialis gangeticus): a review. J. Bombay Nat. Hist. Soc., 79:531-548.

\section{AUTHOR'S ADDRESS}

Sunil Lal Rajbhandari ${ }^{1}$

Amrit Science Campus, Tribhuvan University, Lainchaur, Kathmandu, Nepal

(email: sunilrajbhandari@hotmail.com)

Paras Mani Acharya²

Patan Multiple Campus, Tribhuvan University, Lalitpur, Nepal 